\title{
STUDI AWAL PEMBUATAN PUPUK KCL BERBAHAN DASAR SABUT KELAPA (Cocos nucifera) PADA TANAMAN CABAI RAWIT (Capsicum frutescens L.)
}

\author{
Dian Nirwana Harahap \\ Fakultas Keguruan dan Ilmu Pendidikan Universitas Islam Sumatera Utara, Medan, Indonesia \\ e-mail: dian_pangan@fkip.uisu.ac.id
}

\begin{abstract}
This research told about making $\mathrm{KCl}$ Fertilizer base coconut waste and applied to the cayenne pepper plant (Capsicum frutescens L.). Two samples used as initial experiments. The purpose of this study was to determine the initial growth of the cayenne plant (Capsicum frutescens L.) when treated with the addition of $\mathrm{KCl}$ fertilizer. The method used is to inculcated cayenne pepper plant seeds for three weeks and transferred in small polybags with the same soil nutrient state. Samples C0 (without KCl Fertilizer) and $\mathrm{C} 1$ (KCl Fertilizer Treatment). Plants are observed every week for two months. The results showed that $\mathrm{C} 1$ plants grew faster than $\mathrm{C} 0$.
\end{abstract}

Keyword: Fertilizer, $\mathrm{KCl}$, coconut waste, cayenne pepper plant, Capsicum frutescens L.

\begin{abstract}
Abstrak
Penelitian ini menceritakan tentang pembuatan pupuk $\mathrm{KCl}$ berbahan dasar sabut kelapa dan diaplikasikan pada tanaman cabai rawit (Capsicum frutescens L.). Dua sampel digunakan sebagai percobaan awal. Tujuan dalam penelitian ini untuk mengetahui pertumbuhan awal tanaman cabai rawit (Capsicum frutescens L.) bila diberi perlakuan dengan penambahan pupuk $\mathrm{KCl}$. Metode yang dilakukan yaitu dengan menyemai biji cabai rawit selama tiga minggu dan dipindahkan dalam polibek kecil dengan keadaan nutrisi tanah yang sama. Sampel C0 (Tanpa Pupuk KCl) dan C1 (Perlakuan Pupuk KCl). Tanaman diamati setiap minggu selama dua bulan. Hasil penelitian menunjukan bahwa tanaman $\mathrm{C} 1$ lebih cepat pertumbuhannya dibanding dengan $\mathrm{C} 0$.
\end{abstract}

Kata Kunci: Pupuk, KCl, Limbah Sabut Kelapa, Cabai Rawit, Capsicum frutescens L.

\section{PENDAHULUAN}

Masalah yang dihadapi masyarakat petani adalah pupuk kimia dengan harga tinggi. Selain itu pemakaian pupuk kimia yang berlebih dapat merusak tanah sebagai media tanam yang utama. Penggunaan pupuk Kalium telah direkomendasikan sejak tahun 1977 dan telah digunakan oleh petani. Pengadaan pupuk Kalium harus diimpor. Pada saat ini harga pupuk buatan cenderung semakin meningkat, hal ini disebabkan sebagian bahan pupuk diimpor seperti halnya pupuk KCl. Sedangkan pupuk Urea membutuhkan energi yang cukup banyak dalam prosesingnya, disamping itu usaha budidaya yang intensif juga menyebabkan kerusakan tanah/lahan karena diolah secara terus-menerus (Abdullah, 2010).

Sabut kelapa merupakan limbah dari buah kelapa yang sering dimanfaatkan orang sebagai bahan dasar pembuatan keset kaki. Sekitar 35\% dari bagian buah kelapa. Disisi lain serabut kelapa banyak mengandung unsur hara kalium yang sangat dibutuhkan oleh tanaman. Dalam penelitian yang dilakukan oleh Sianturi (2014) Sabut kelapa memiliki kandungan unsur-unsur hara dari alam yang sangat dibutuhkan tanaman yaitu berupa Kalium $(\mathrm{K})$, Kalsium (Ca), Magnesium ( $\mathrm{Mg}$ ), Natrium ( $\mathrm{Na}$ ) dan Fospor. Kalium merupakan salah satu unsur yang diperlukan bagi tanaman, karena salah satu sifat positif dari kalium adalah 
menghambat klorosis pada daun. Kalium adalah suatu satu unsur hara esensial yang di butuhkan oleh tanaman dalam jumlah besar. Kalium di serap tanaman dalam bentuk ion $\mathrm{K}+$ di dalam tanah. Ion ini bersifat dinamis, sehingga mudah tercuci tanah berpasir dan tanah dengan $\mathrm{pH}$ rendah.

Pupuk $\mathrm{KCl}$ pada umumnya merupakan pupuk buatan dari bahan anorganik. Dalam penelitian ini $\mathrm{KCl}$ yang dimaksud adalah pupuk $\mathrm{KCl}$ yang berasal dari limbah serabut kelapa yang di maserasi selama beberapa hari. Penelitian sebelumnya telah dilakukan oleh Wijaya pada tahun 2017 tentang aplikasi pupuk cair dari sabut kelapa pada tanaman jagung. Hasil penelitiannya mengungkapkan bahwa dengan semakin bertambahnya volume pupuk cair yang diberikan maka kelarutan dan ketersediaan hara juga semakin meningkat (Wijaya,2017).

Produksi cabai rawit tahun 2013 - 2018 selalu mengalami kenaikan. Produksi cabai rawit pada tahun 2018 mengalami kenaikan sebesar 15,82 persen dibandingkan tahun sebelumnya. Produksi nasional cabai rawit mencapai angka 1,34 Juta Ton. Sehingga kebutuhan akan cabai rawit selalu meningkat dari tahun-ketahun.

Penelitian ini bertujuan untuk mengetahui pertumbuhan awal tanaman cabai rawit yang diberi perlakuan menggunakan penambahan pupuk $\mathrm{KCl}$ yang berasal dari limbah serabut kelapa.

\section{METODE}

Penelitian ini merupakan penelitian eksperimental. Dimana bahan utama yang digunakan adalah limbah serabut kelapa dan tanaman cabai rawit. Penelitian ini dilaksanakan Selama 6 bulan di laboratorium PMIPA Fakultas Keguruan dan Ilmu Pendidikan Universitas Islam Sumatera Utara. Dalam penelitian ini bertujuan untuk mengetahui pertumbuhan dari cabai rawit. Alat yang digunakan adalah beaker glass ukuran $1000 \mathrm{ml}$, sekop, gunting, baskom, botol sampel. Bahan yang digunakan adalah sabut kelapa, air bersih, tali, polibek, tanah, tanaman cabai rawit. Langkah awal dalam penelitian ini adalah pembuatan pupuk cair $\mathrm{KCl}$ dari limbah sabut kelapa. Persiapan sampel penelitian dan aplikasi pupuk $\mathrm{KCl}$ serabut kelapa terhadap pertumbuhan awal cabai rawit. Sehingga dapat diketahui pertumbuhan tanaman cabai rawit dengan penambahan pupuk $\mathrm{KCl}$ sabut kelapa. Pupuk $\mathrm{KCl}$ dibuat dengan cara dibersihkan sabut kelapa. Sabut kelapa tersebut digunting kemudian dimaserasi selama 14 hari (diaduk setiap tiga hari sekali). Setelah 14 hari, kemudian dilakukan penyaringan sehingga memperoleh pupuk cair $\mathrm{KCl}$ yang siap digunakan. Sebelumnya pupuk tersebut dikemas dalam botol khusus pupuk cair.

\section{Prosedur dalam penelitian ini adalah sebagai berikut:}

\section{Proses Persiapan Tanaman cabai rawit}

Biji cabai rawit disemai pada polibek yang telah berisi tanah dengan kondisi yang sama. Selama 21 hari diamati pertumbuhannya. Tanaman cabai rawit yang telah memiliki 3 lembar daun, dipindahkan ke dalam polibek dan diberi lebel $\mathrm{C} 0$ dan $\mathrm{C} 1$ dengan ketentuan sebagai berikut :

a. $\mathrm{C} 0=$ Tanaman cabai rawit tanpa penambahan pupuk cair $\mathrm{KCl}$.

b. $\mathrm{Cl}=$ Tanaman cabai rawit dengan pupuk cair $\mathrm{KCl}$ setiap 1 minggu sekali.

\section{Proses Pembuatan Pupuk KCl dari Serabut Kelapa}

Serabut kelapa dibersihkan dari pengotornya, kemudian digunting hingga rapi. Serabut kelapa dimasukkan kedalam beaker glass ukuran $1000 \mathrm{ml}$ yang telah disiapkan. Kemudian ditambahkan air bersih ke dalam beaker glass tersebut hingga serabut kelapa terendam sempurna. Maserasi selama 14 hari. Setelah 14 hari, dilakukan filtrasi hingga membentuk filtrat berupa pupuk cair $\mathrm{KCl}$ dari serabut kelapa. Kemudian dikemas dalam wadah pupuk cair.

\section{Proses Pemberian Pupuk Pada tanaman Cabai Rawit}


Tanaman cabai rawit yang telah dipindahkan dari persemaiannya, diberi perlakuan sesuai dengan label yang telah ditentukan yaitu $\mathrm{C} 0$ dan $\mathrm{C} 1$. Kemudian diamati dan dilakukan pengukuran pertumbuhan tanaman.

a. Pengukuran Batang

b. Pengukuran Daun

4. Proses Pengamatan dan Pengukuran Pertumbuhan Tanaman Cabai Rawit

a. Pengukuran Batang

b. Pengukuran Daun

Data dalam penelitian ini diperoleh melalui pengukuran dan pengamatan secara langsung. Instrument yang digunakan adalah mistar sederhana dengan panjang $30 \mathrm{~cm}$. Setelah data diperoleh kemudian ditabulasi dalam tabel data untuk melihat perbedaan pertumbuhan diantara keduanya.

\section{HASIL DAN PEMBAHASAN}

Berdasarkan penelitian yang telah dilakukan sesuai dengan prosedur, maka diperoleh gambar sebagai berikut :

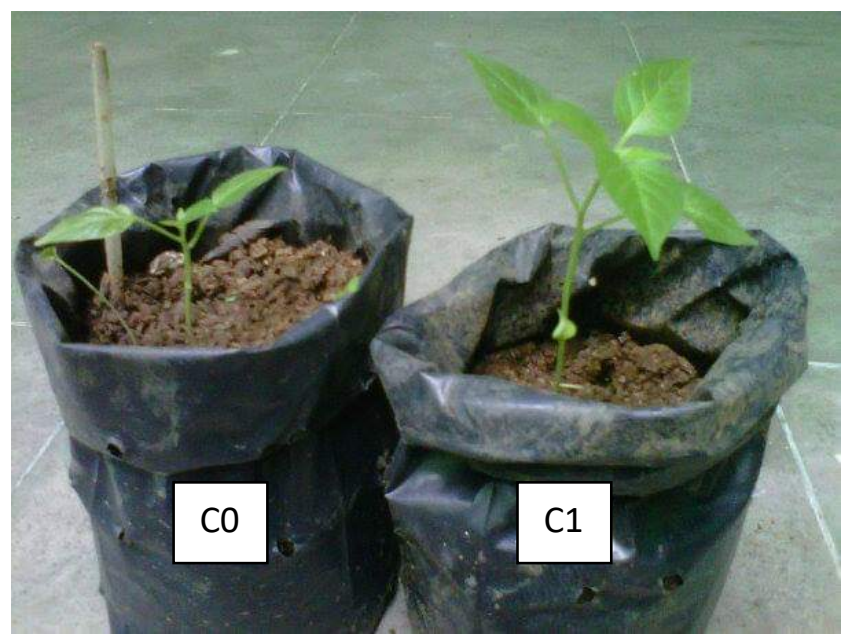

Gambar 1. Tanaman Cabai Rawit C0 dan $\mathrm{C} 1$

Berdasarkan Gambar 1 dapat dilihat bahwa pertumbuhan tanaman cabai rawit yang diberi perlakuan penambahan pupuk $\mathrm{KCl}(\mathrm{C} 1)$ lebih cepat pertumbuhannya dibanding dengan tidak menggunakan pupuk $\mathrm{KCl}(\mathrm{C} 0)$.

Tabel 1. Data Hasil Pengamatan Tanaman Cabai rawit

\begin{tabular}{ccccc}
\hline No & Tanaman Cabai Rawit & Jumlah Daun & Tinggi Batang (cm) & Warna Daun \\
\hline 1 & C0 & 3 & 3 & Hijau \\
2 & C1 & 5 & 5 & Hijau Muda \\
\hline
\end{tabular}

Berdasarkan data tabel 1, selama dua bulan tanaman cabai rawit $\mathrm{C} 0$ memiliki jumlah daun 3 helai dan tinggi batang mencapai $3 \mathrm{~cm}$, sedangkan tanaman cabai rawit $\mathrm{C} 1$ memiliki jumlah daun 5 helai dan tinggi batang $5 \mathrm{~cm}$. Berdasarkan penelitian yang telah dilakukan, daun tanaman cabai rawit $\mathrm{C} 1$ tampak lebih lebar dan lebih transparan (lebih muda). Daun dan batang pada tanaman $\mathrm{C} 1$ lebih muda dibangkan dengan $\mathrm{C} 0$, ini disebabkan oleh kurangnya pigmen pada tanaman $\mathrm{C} 1$. Akan tetapi pada $\mathrm{C} 1$ mengalami pertumbuhan batang dan daun yang sangat cepat.

Pada kesempatan lain dilakukan pula penelitian dengan empat sample dengan variasi pemupukan menggunakan pupuk $\mathrm{KCl}$ berbahan dasar sabut kelapa. Tanaman dengan kode 
C1-2 dilakukan pemupukan 1 minggu sekali; C2-2 dilakukan pemupukan 2 minggu sekali; C3-3 dilakukan pemupukan 3 minggu sekali dan C4-2 dilakukan 4 minggu sekali. Control (C0-2) tetap menggunakan tanaman cabai rawit tanpa penambahan pupuk $\mathrm{KCl}$ berbahan dasar sabut kelapa. Hasil penelitian dapat dilihat pada gambar berikut.

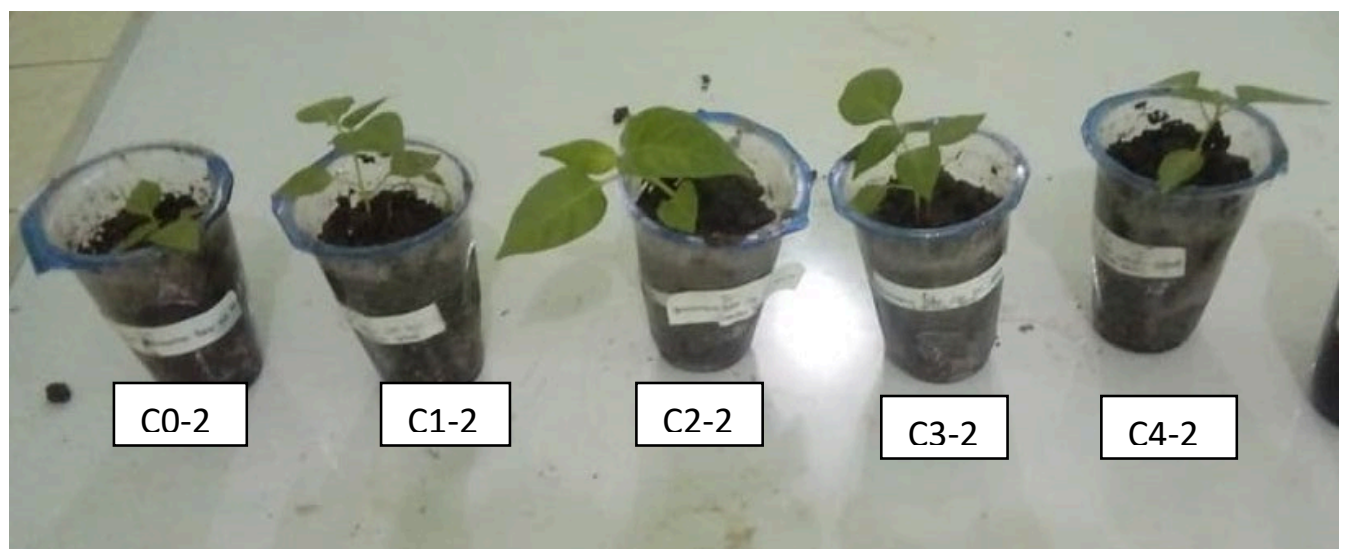

Gambar 2. Tanaman Cabai Rawit dengan Variasi pemupukan $\mathrm{KCl}$ berbahan dasar Sabut Kelapa

Tabel 2. Data Hasil Pengamatan Tanaman Cabai rawit

\begin{tabular}{ccccc}
\hline No & Tanaman Cabai Rawit & Jumlah Daun & Tinggi Batang (cm) & Warna Daun \\
\hline 1 & C $0-2$ & 3 & 2.5 & Hijau \\
2 & C $1-2$ & 5 & 5 & Hijau Muda \\
3 & C2-2 & 5 & 6 & Hijau Muda \\
4 & C $3-2$ & 5 & 4.5 & Hijau Muda \\
5 & C4-2 & 5 & 4.5 & Hijau Muda \\
\hline
\end{tabular}

Berdasarkan tabel 2, tanaman cabai rawit dengan penambahan pupuk $\mathrm{KCl}$ berbahan dasar serabut kelapa, memiliki pertumbuhan batang yang cepat. Terlihat pada data tabel perlakuan ulangan pada C2-2, bahwa tinggi batang mencapai $6 \mathrm{~cm}$ dan memiliki 5 helai daun. $\mathrm{Hal}$ ini disebabkan di dalam pupuk $\mathrm{KCl}$ berbahan dasar serabut kelapa, terdapat kandungan kalium yang sangat dibutuhkan tanaman cabai rawit dalam pertumbuhanya. Sejalan dengan hasil penelitian yang dilakukan oleh wijaya (2017) bahwa penambahan pupuk $\mathrm{KCl}$ berbahan dasar sabut kelapa dapat meningkatkan unsur hara pada tanah sehingga pertumbuhan tanaman jagung lebih cepat. Akan tetapi berdasarkan pengamatan yang dilakukan, daun pada $\mathrm{C} 1, \mathrm{C} 1-2, \mathrm{C} 2-2, \mathrm{C} 3-2, \mathrm{C} 4-2$ tampak berwarna hijau lebih muda disbanding dengan $\mathrm{C} 0$ dan $\mathrm{C} 0$-2. Hal ini perlu diadakan penelitian lebih lanjut tentang warna daun yang dihasilkan tanaman cabai rawit terlihat lebih hijau muda. Diduga bahwa kandungan klorofil daun pada sample $\mathrm{C} 1, \mathrm{C} 1-2, \mathrm{C} 2-2, \mathrm{C} 3-2, \mathrm{C} 4-2$ lebih sedikit dibanding dengan kontrolnya (C0 dan $\mathrm{C} 0$ 2).

Menurut Pratama dan Laily (2015), faktor-faktor yang mempengaruhi pembentukan klorofil antara lain gen, cahaya, dan unsur Nitrogen, Magnesium, Besi sebagai pembentuk dan katalis dalam sintesis klorofil. Akibat dari penggunaan pupuk yang mengandung kalium biasanya ditimbulkan oleh ion-ion pengiring (terutama $\mathrm{Cl}^{-}$). Dalam hubungan dengan pengaruh anion, $\mathrm{Cl}^{-}$memberikan pengaruh yang kurang baik pada tanaman yang sensitif terhadap serapan $\mathrm{Cl}^{-}$yang tinggi. Reaksinya bersifat sedikit masam. Namun pemupukan dengan $\mathrm{KCl}$ terus menerus dapat meningkatkan kadar Al dalam tanah.

Bila terjadi pemakaian berlebihan dari kalium, karena kepekatan kalium dalam media tumbuh tinggi serapan, maka kadar magnesium dalam daun dapat menurun, kadang-kadang mencapai tingkat rendah sehingga fotosintesis dapat terganggu. Kandungan klorofil pada 
daun akan mempengaruhi reaksi fotosintesis. Ketika reaksi fotosintesis tidak maksimal, senyawa karbohidrat yang dihasilkan juga tidak bisa maksimal (Posumah, 2017).

Berdasarkan penelitian ini, pemberian pupuk kalium sedikit tapi sering lebih baik dari pemberian sekaligus banyak atau kurang sering. C2-2 memiliki pertumbuhan batang yang sangat cepat. Hal ini ini wajar mengingat adanya pemakaian berlebihan oleh tanaman, pekanya unsur kalium tehadap pencucian dan kemungkinan kelebihan kalium diikat tanah. Dua hal tersebut merupakan penyebab utama tidak disarankannya pemberian sekaligus banyak.

\section{KESIMPULAN}

Berdasarkan hasil penelitian ini maka dapat disimpulkan bahwa Pupuk $\mathrm{KCl}$ dari limbah sabut kelapa dapat menutrisi tanah sehingga baik untuk pertumbuhan awal batang tanaman cabai rawit. Pertumbuhan tanaman cabai rawit yang diberi perlakuan lebih cepat dibandingkan dengan pertumbuhan tanaman cabai rawit yang tidak diberi perlakuan penambahan pupuk $\mathrm{KCl}$ berbahan dasar limbah sabut kelapa. Penelitian berikutnya disarankan untuk melihat pertumbuhan batang, daun dan buah pada usia 4-6 bulan dan menguji kandungan klorofil pada daunnya.

\section{UCAPAN TERIMA KASIH}

Peneliti mengucapkan banyak terima kasih kepada Fakultas Keguruan dan Ilmu Pendidikan Universitas Islam Sumatera Utara (FKIP UISU) yang telah memfasilitasi penelitian ini, Teman sejawat dan Kepala Laboratorium PMIPA FKIP UISU.

\section{DAFTAR PUSTAKA}

Abdullah, S.2010. Efektivitas Pupuk Kalium dan/atau Bahan Organik terhadap pertumbuhan dan Hasil Padi Sawah pada Lahan Sawah Kahat Kalium di Kasang, Kabupaten Padang Pariaman. http://balittanah.litbang.pertanian.go.id/ind/dokumentasi /prosidingsemnas2010/syahrial.pdf. di akses pada tanggal 20 Juni 2019

Pratama \& Laily, 2015. Analisis Kandungan Klorofil Gandasuli (Hedychium gardnerianum Shephard ex Ker-Gawl) Pada Tiga Daerah Perkembangan Daun yang Berbeda. Seminar Nasional Konservasi dan Pemanfaatan Sumber Daya Alam 2015. Pendidikan Biologi, Pendidikan Geografi, Pendidikan Sains, PKLH - FKIP UNS. Universitas Islam Negeri Maulana Malik Ibrahim Malang.

Posumah, Dany. 2017. Uji Kandungan Klorofil Daun Tanaman Cabai Merah (Capsicum annum L.) Melalui Pemanfaatan Beberapa Pupuk Organik Cair. JURNAL MIPA UNSRAT ONLINE 6(2) 101-104. FMIPA, UNIMA, Manado.

Sianturi, Daniel Arief, dkk. 2014. Penggunaan Pupuk KCl dan Bokashi Pada Tanaman Ubi Jalar (Ipomae batatas). Jurnal Dinamika Pertanian Volume XXIX Nomor 1 April 2014 (37-44).

Wijaya, Ray, Damanik, M. Madjid B, Fauzi. 2017. Aplikasi Pupuk Organik Cair dari Sabut Kelapa dan Pupuk Kandang Ayam Terhadap Ketersediaan dan Serapan Kalium serta Pertumbuhan Tanaman Jagung pada Tanah Inceptisol Kwala Bekala. Jurnal Agroteknologi FP USU Volume 5 Nomor 2, April 2017 (33): 249-255 